\title{
Impact of Interest Rate on Stock Prices Volatility: A Case of Textile Sector of Karachi Stock Exchange
}

\author{
MUHAMMAD SOHAIL KHALIL \\ Assistant Professor, City University of Science and I.T, Peshawar \\ khalilims@gmail.com \\ MUHAMMAD AAMIR NADEEM \\ Assistant Professor, City University of Science and I.T, Peshawar \\ MUHAMMAD TAHIR KHAN \\ Lecturer, Institute of Business Studies and Leadership \\ Abdul Wali Khan University, Mardan \\ mtahir@awkum,edu.pk
}

\begin{abstract}
This study investigates the relationship between interest rate and stock price volatility in textile sector of Karachi Stock Exchange. Initially, EWMA model is used to calculate the volatility of stock prices. Stock returns are calculated as a proxy to stock prices. Afterwards, linear regression analyzes the relation between interest rate and stock price volatility. The significance $F$ change is below the limit of 0.05 showing goodness-to-fit of the model to project the responses from predictor to be reliable. The research concludes the relationship of interest rate with volatility of stock prices as slightly inverse in nature.
\end{abstract}

Keywords: Interest Rate, Stock Price Volatility, KSE

\section{Introduction}

Varied results were produced whenever attempts were made to test the relation between the interest rates and stock prices; however the literature indicates not exact but inverse relation between interest rates and stock prices (Kadir, Selamat, Masuga \& Taudi, 2011). Leon (2008) came to a related conclusion about the Korean stock exchange. Zafar, Urooj and Durrani (2008) supported the same argument about returns in the market and interest rate that there is certainly a negative and important relationship between these two variables in Karachi stock exchange and a slightly negative relationship between interest rates and stock prices volatility.On the other hand one school of thought including Shankan and Jay (1990) and Campbell (1987) followed the argument that change in the interest rate positively affects the volatility of stock prices returns of the market. A similar argument was presented with some new results by Shah Rehman, Kamal and Abbas (2012)that there does not simply exist a straight negative relationship between KSE-100 index and interest rate in short run. They further explained that the revision of policy in 2009 by the central bank did not enhanced the morale of the market. However, out of three, it came down in two cases within the first three days of decrease in the interest rate. Contrary, the market observed fluctuations in 2010 even when the key policy rate was changed. 


\subsection{Objective of the Study}

The primary objective of this study is empirically analyze the relation between interest rate and stock prices volatility in Karachi stock exchange textile sector in other words to measure the impact on volatility in stock prices due to interest rate. However, to achieve the primary objective, there is a secondary objective which will be achieve first. Secondary objective include finding the volatility of stock prices. Further the secondary objective serves as mean to achieve the primary objective.

\section{Review of Literature}

Interest rate and stock prices are two important factors of the economic growth and numerous theories depict that there is some sort of relationship between interest rate and stock prices (Shah, Rehman, Kamal \& Abbas, 2012). Researchers have done a lot research to find out the relationship between interest rate and stock prices. However, these studies exhibit different results (Serletis \& king, 1997). Some authors like Moya, Lapena and Sotos (2013) said that increase in interest rate inversely affects stock price. They argued that since it increases the interest expense of highly leveraged companies, as a result cash flows available at the time for future dividend payments reduces, thus share price becomes negatively affected. On the other hand researcher like Uddin and Alam (2009) found that interest rate and stock prices are negatively related to each other. It can be observed that as interest rate increases, the liquidity in the stock market reduces and hence stock prices changes (Fischbacher \& Zeisberger, 2011).

Influence of the interest rate on stock prices is an important phenomenon to regulatory authorities and investors. Regulatory authority which controls the monetary policy makes necessary changes in the rate of interest to control money supply in the market. As a result, investors have to respond to this action of the authorities for the reason that it affects the required rate of return on financial assets (Chen, Roll \& Ross, 1986). Goske and Roll (1983) found that there happens to be an opposite relationship between interest rate and stock prices. They further clarified their argument that high interest rate signals towards high unemployment, less economic activity and therefore less earnings of the firms. Adding to the argument, Shah et al. (2012) also mentioned that if the company has greater financial liabilities and lesser financial assets, then the real value of financial assets will be affected by the fluctuation in interest rate and it should benefit the firm instead of reducing its share prices.

Zordan (2005) concluded that past indication demonstrates that interest rate and stock prices are negatively co related, the same fact was witnessed back in 1980's; specifically at the time of post-world war II. If the era from the late 1940's till the mid of 1960 's it has been observed that inflation and interest rate both were low and stable. Hence stock prices were going well; not only in nominal terms but also in real terms. Historic evidence shows negative relationship between assets sensitive to interest rate including bonds and stock prices the relationship of interest rate and stock prices can likewise be witnessed in the period from 1877 to 1906, from 1906 to 1920, from 1920 to 1929, from 1929 to 1949 and also from 1949 to 1966.

Contrary to this, Flannery and James (1984) have a different argument related to changes in interest rate. They reasoned that instead of having decrease in stock prices, increase in interest rate should benefit in the firms with more financial liabilities as compared to 
financial assets (not real assets).Mukit (2013) presented the argument by investigating through granger causality test that increase in interest rate affects stock prices negatively in the Bangladeshi Market. The effect is seen in the long run more significantly. The scholar termed it as systematic risk and recommended that this risk should be taken into account by the investors while making investment and portfolio decisions. A similar type of argument was presented by Uddin and Alam (2009) that some countries have negative relationship between the interest rate and change in the stock prices but positive relationship between change in the interest rate and change in the stock prices they also found negative relationship between these variables in both situations for Bangladesh, Colombia, Italy and S. Africa.

At firm level, interest rate variation may affect stock prices in numerous ways but the degree of the effect may vary from firm to firm (shah et al., 2012). Moya et al. also reasoned that stock prices become negatively affected by the increase in the interest rate for the reason that it increases the expense of interest for the companies which are highly leveraged. This reduces the cash flow available for future dividend payments. However, they also mentioned about the recent work which has suggested that now interest rate has less exposure over the time mainly because of the availability of better tolls for management of its risk.

According to the previous work done, there exists a negative relationship between interest rate and stock returns never the less the relationship is not that much binding. The price index 200 of Korea and its weekly negotiable deposits were studied and the study found that there does exist a kind of strong predictive power for stock returns and weak for volatility (Kadir, Selamat, Masuga \&Taudi, 2011).Zafar and Durani (2008) who worked on monthly returns of Karachi stock exchange favored these findings. They observed negative and significant relationship between market return and interest rate. However, and insignificant negative relationship exists between variance and interest rate.

Adjasi (2009) claimed that not only uncertainty but also the rate of interest intensifies the volatility of stock prices. His argument is based about the effect of macroeconomic uncertainty on stock prices volatility and used EGARCH model to show the significance of positive spillovers of volatility of cocoa prices and interest rate to stock prices in Ghana stock exchange. However, in the case of gold prices, oil prices in and money supply, a significant negative volatility. Most of the work done to find out the impact of macroeconomic variables like interest rate on stock prices volatility emphasizes on the developed markets. However, in the near past, considerable amount of work is evolving on the macroeconomic fluctuations and stock markets variations in the emerging markets mainly focused on South America, Eastern Europe and Asian markets yet limited on African markets (Ajasi, 2009).

West (1986) mentioned in his paper that stock prices volatility can also be reasoned to be the outcome of expected presented discounted value of dividend. While studying stock price volatility, $\mathrm{Xu}(2006)$ also made his argument related to the impact of stock price volatility on the strategy for R \& D in the biotech industry by particularly taking the case of drug discovery. Substantial movements of stock prices are caused by two important economic variables; real interest rate and GNP. It was found that interest 
rate was the cause of too much short term stock prices volatility. It is not claimable to predict exact turning points of real interest rate. However; basic analysis can definitely contribute to considerable amount to detect the probable average value of real interest rate. These types of models are helpful in setting the asset mix policy and forecast comprehensive trends of stock prices (Spiro, 1990). Subhani, Hassan, Moten And Osman (2011) explored the volatility of equity market in comparison to stock returns with various countries using GARCH 1-1 model and found the interest rates and exchange rates catalyze the stock returns volatility for the economies examined by them except of Hong Kong. This particular research talks about the impact of interest rate on the stock prices volatility in non-financial textile sector companies listed at Karachi stock exchange. The effect on volatility stock prices caused by the interest rate is measured between the time periods of 2007-2014.

\subsection{Proposed Hypothesis}

$H_{0}=$ Interest rate has negative impact on stock price volatility.

$H_{1}=$ Interest rate has positive impact on stock price volatility.

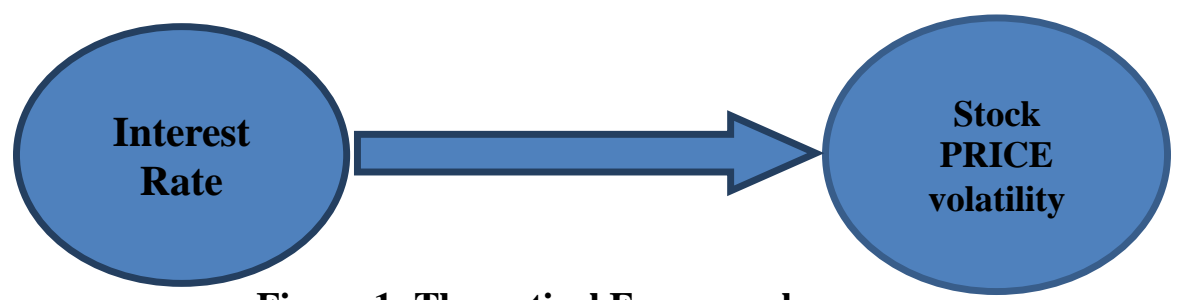

\section{Methodology}

Figure 1: Theoretical Framework

\subsection{Variables Studied}

The study is based on the relationship between two variables; interest rate and stock price volatility. As both the variables are quantitative in nature the effects of all other corresponding variables are ignored.

\subsubsection{Independent Variable}

Interest rate is taken as independent variable in this study. For this research, increase and decrease of interest rate will be taken as independent of any other changes in other variables. Shah et al. (2012) described interest rate as a rent of money lent as loan for the lenders and on the other side from the borrowers point of view, borrowing cost for money borrowed. Interest rate is the fee of borrowing for borrowers and income for the lenders risk associated with it is known as key source of uncertainty for the companies (Moya, Lapena \& Sotos, 2013). Riske free rate i.e. 06 months T-bill rate is taken as proxy for interest rate (shah et al. (2012).

\subsubsection{Dependent Variable}

Stock prices volatility is taken as dependent variable of this research stock price is the price of single share of the company. When investor pays the price of the share, it indicates that he buys the dividends paid on the share and its earnings of the company are distributed among its owners hence the market price depicts that price to be paid for the ownership of the company (Gorden, 2009). The effect of interest on stock prices is negative because as the Risk free rate increases, the discount rate also increases; hence 
investors can gain more return in less risky and risk free securities as compared to stocks. This decreases the demand of stocks and hence the stock prices go down. Volatility can be defined as the disparity of stock prices which will be going to take place or has happened in the past. Positive and negative; both kinds of volatility exist. Usually positive volatility is a good sign from shareholder's perspective while on the other hand negative volatility is matter of concern form investor's point of view. High volatility is in fact disparity or variations in prices of security during short period of time and low volatility mean fewer variations in specific time period.

\subsection{Data Set}

Monthly panel data of stock prices is taken for the period of 07 years i.e. from 2008 to 2014 of the population which is textile sector of KSE 30 companies are selected for the study using simple random sampling as a technique. Whereas proxy for interest rate is 06 months $\mathrm{T}$ - bill rate.

\subsection{Data Collection Method and Procedure}

Secondary data is required for the research and is taken from the official website of Karachi stock exchange (KSE) data storage sites including opendoors.pk and business recorder. T-bill rate i.e. interest rate data is taken form the official website of State bank.

\subsection{Statistical Test}

Exponentially moving average (EWMA) is used to find the volatility of the stock prices, whereas for the impact of interest rate linear regression is used;

$\mathrm{V}_{\mathrm{sp}}=\alpha_{0}+\alpha_{1} \mathrm{i}+\mathrm{U}_{\mathrm{t}}$

Where

$\mathrm{V}_{\mathrm{sp}}$ represents stock price volatility

$\alpha_{0}$ represents constant

irepresents interest rate at given time

$\alpha_{1}$ represents parameter of change in $i$

$\mathrm{U}_{\mathrm{t} \text { represents errors }}$ in the calculations which have the possibility to occur in a given time.

$\delta^{2}{ }_{t}=\lambda \delta^{2}{ }_{t-1}+(1-\lambda) R^{2}{ }_{t-1}$

Where

$\delta^{2}{ }_{t}=$ volatility

$\lambda=$ Exponential weighted Co efficient

Value of $\lambda$ is taken as 0.94

$\mathrm{R}^{2}=$ represents square of stock prices 


\section{Analysis and Findings}

Table 4.1: Model Summary ${ }^{b}$

\begin{tabular}{|c|c|c|c|c|c|c|c|c|c|c|}
\hline \multirow{2}{*}{ ModeI } & \multirow{2}{*}{$\mathbf{R}$} & \multirow[b]{2}{*}{$\begin{array}{l}\text { R } \\
\text { square }\end{array}$} & \multirow[b]{2}{*}{$\begin{array}{l}\text { Adjusted } \\
\text { R square }\end{array}$} & \multirow{2}{*}{$\begin{array}{l}\text { Std. } \\
\text { Error of } \\
\text { the } \\
\text { Estimate }\end{array}$} & \multicolumn{5}{|c|}{ Change statistics } & \multirow{2}{*}{$\begin{array}{l}\text { Durbin } \\
\text { Watson }\end{array}$} \\
\hline & & & & & $\begin{array}{l}\mathrm{R} \\
\text { square } \\
\text { change }\end{array}$ & $\begin{array}{c}\text { F } \\
\text { change }\end{array}$ & df 1 & df 2 & $\begin{array}{l}\text { Sig. F } \\
\text { change }\end{array}$ & \\
\hline 1 & .064 & 0.004 & .004 & $\begin{array}{l}.003108 \\
0\end{array}$ & .004 & 10.340 & 1 & 2488 & .001 & 1.451 \\
\hline
\end{tabular}

a. Predictors: (Constant), Interest Rate

b. Dependent variable: Stock Returns Volatility

The adjusted $\mathrm{R}$ square is $0.4 \%$ which explains the proportion of variation in the stock prices volatility explained by the interest rate. The value of adjusted $\mathrm{R}$ square is less, albeit the model is strongly reliable. The reason for its reliability is that there is only one independent variable due to time and resource constraint. Conversely more independent variables will show more effect in adjusted $R$ square. The significance $F$ change is .001 which is below .05 showing that the ability of the model taken for the research is durable enough to explain the variables. As the model is strongly able to explain the relation between the variables therefore out puts resulting from the said model are reliable stating that model can strongly predict the relationship between the interest rate and stock prices volatility of textile sector of KSE, Very low value of Standard error also suggesting less error in the prediction of volatility of stock prices.

\begin{tabular}{|l|c|c|c|c|c|c|c|}
\hline \multirow{2}{*}{ Model } & $\begin{array}{l}\text { Tnstandardized } \\
\text { Coefficients }\end{array}$ & $\begin{array}{l}\text { Standardized } \\
\text { Coefficients }\end{array}$ & \multirow{2}{*}{$\mathbf{t}$} & Sig & \multicolumn{2}{|c|}{$\begin{array}{c}\text { Collinearity } \\
\text { Statistics }\end{array}$} \\
\cline { 2 - 6 } & $\mathrm{B}$ & $\begin{array}{c}\text { Std. } \\
\text { Error }\end{array}$ & Beta & & & Tolerance & VIF \\
\hline $\begin{array}{l}1 \\
\text { (constant) }\end{array}$ & .002 & .000 & & 4.958 & .000 & & \\
$\begin{array}{l}\text { Interest } \\
\text { Rate }\end{array}$ & 0.12 & .004 & -.064 & -3.216 & .001 & 1.000 & 1.000 \\
\hline
\end{tabular}

a. Dependent variable: Stock returns Volatility

The constant unstandardized B value is 0.002 . The magnitude of unstandardized beta is trivial. However, the negative sign with the beta is significant. Demonstrating that interest rate is inversely related thus confirming the alternative hypothesis. So when the interest rate is increased stock prices observe less volatility in textile sector of KSE. Likewise, standardized co efficient beta value of interest rate is -0.64 showing the inverse correlation by the value of -0.64 between them with negative sign indicating inverse relation. 


\section{Conclusion}

The model comes out to be strong in predicting the responses of stock prices volatility by interest rate with very less error and more accurate forecasting. The study also concludes the relationship between stock price volatility and interest rate to be inverse. However, this negative relationship is not very substantial. The result of this study follows the previous researches together with Moya et.al (2013) which concluded that there is very little negative relation between interest rate and stock prices in Spanish market but if industries like utilities, banking, food and beverages have significant negative relationship of interest rate and stock prices. Same like Shah et al. (2012) also mentioned that interest rate fluctuations in either direction do give shock to stock prices negatively; however they come to their status quo after some time thus there exists some relation between the two said variables. Uddin and Alam (2009) came to the parallel conclusion to up keep the theoretical argument which says that interest rate and stock prices are negatively related.

\section{References}

BixiaXu, (2006). R\&D strategy and stock price volatility in the biotechnology industry. Review of Accounting and Finance, Vol. 5(1), pp.59-71.

Campbell, J. Y. (1987). Stock Returns and the Term Structure. Journal of Financial Economics, 18, 373-399.

Charles, K.D. Adjasi, (2009). Macroeconomic Uncertainty and conditional stock price volatility in frontier African markets. The Journal of Risk Finance, Vol.10(4), pp. 333-349.

Chen, N. F., Roll, R., \& Ross, S. A. (1986). Economic Forces and the Stock Market. The Journal of Business, 59 (3), 383 - 403.

Muktadir - Al -Mukit, D. (2013) The Effects of Interest Rates Volatility on Stock Returns: Evidence from Bangladesh. Int. J. Manage. Bus. Res., 3 (3), 269-279

Fischbacher, U. Hens, T. \& Zeisberger, S. (2011). The impact of interest rate policy on stock market bubbles and trading behavior. Published at Zurich Open Repository and Archive, pp 1-5

Flannery, M. J., \& James, C. M. (1984). The Effect of Interest Rate Changes on the Common

Geske, R \& Roll, R. (1983). The Fiscal and Monetary Linkage between Stock Returns

Kadir, H. B. A., Selamat, Z., Masuga, T., \& Taudi, R. (2011). Predictability Power of Interest Rate and Exchange Rate Volatility on Stock Market Return and Volatility: Evidence from Bursa Malaysia. In International Conference on Economics and Finance Research IPEDR (Vol. 4).

Kenneth D. W. (1986). Dividend innovations and stock price volatility. National bureau of economic research. 1050 Massachusetts Avenue Cambridge, MA, USA

Uddin, M. G. S. \& Alam, M. (2009). CRM, Marketing Division, Grameen phone Ltd, Relationship between Interest Rate and Stock Price: Empirical Evidence from Developed and Developing Countries. Published by International journal of business and management, Volume 4(3), pp 1-3

Spiro, P. S. (1990). The impact of interest rate changes on stock price volatility. The Journal of Portfolio Management, 16 (2), 63-68 
Subhani, M. I., Hassan, S. A., Moten, R. M. A. \& Osman, A. (2011). South Asian Journal of Management Sciences, Vol. 5(2), 49-59

Zafar, N., Urooj, F. S., \& Durrani, K. T. (2008). Interest Rate Volatility and Stock Return and Volatility.European Journal of Economics, Finance and Administrative Science and Inflation. The J. Finance, 38 (1): 1-33.

Zordan, D. J., (2005). Stock Prices, Interest Rates, Investment Survival, Published by Econometrica USA, Illinois. 